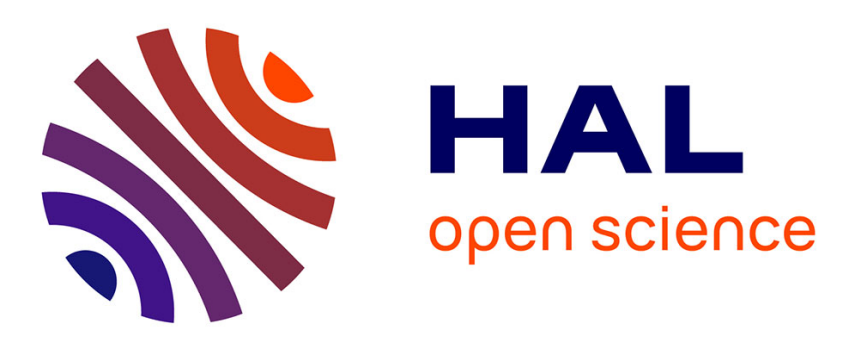

\title{
The Symbolic and Political Appropriation of Scales: a Critical Analysis of the Amazonian Ranchers' Narrative
}

\author{
Romain Taravella, Xavier Arnauld de Sartre
}

\section{To cite this version:}

Romain Taravella, Xavier Arnauld de Sartre. The Symbolic and Political Appropriation of Scales: a Critical Analysis of the Amazonian Ranchers' Narrative. Geoforum, 2012, 43 (3), pp.645-656. 10.1016/j.geoforum.2011.11.009 . halshs-00768262

\section{HAL Id: halshs-00768262 \\ https://shs.hal.science/halshs-00768262}

Submitted on 21 Dec 2012

HAL is a multi-disciplinary open access archive for the deposit and dissemination of scientific research documents, whether they are published or not. The documents may come from teaching and research institutions in France or abroad, or from public or private research centers.
L'archive ouverte pluridisciplinaire $\mathbf{H A L}$, est destinée au dépôt et à la diffusion de documents scientifiques de niveau recherche, publiés ou non, émanant des établissements d'enseignement et de recherche français ou étrangers, des laboratoires publics ou privés. 


\title{
The Symbolic and Political Appropriation of Scales: a Critical Analysis of the Amazonian Ranchers' Narrative
}

\author{
Author: Romain TARAVELLA \\ Post-Doctoral Fellow \\ Institut Hydro-Québec en Environnement, Développement et Société (Institut EDS) \\ Pavillon des Services, local 3800 \\ 2440, Boul. Hochelaga, Université Laval \\ G1K 7P4 Québec Canada
}

Telephone number: 00141865621314654

Fax number: 00141865621317330

Email address: Romain.Taravella@ihqeds.ulaval.ca

\section{Xavier ARNAULD DE SARTRE}

UMR Société environnement territoire

Université de Pau et des Pays de l'Adour / Centre national de la recherche scientifique

Domaine universitaire

$64000 \mathrm{Pau}$

France

Tel: (33) 559407262

Fax: (33) 559407255

Courriel: xavier.arnauld@univ-pau.fr

\begin{abstract}
There are many examples of "local" discourses aiming to delegitimize environmental issues, demands, actions and governance by arguing that they pursue international goals, defined by international actors that do not meet local needs and frequently oppose them. We focus on the narrative held by large ranchers in the Eastern Amazon, which disqualifies the so-called top-down creation of protected areas that jeopardizes the "local development" these actors have, following the narrative, encouraged and sustained for years. Through the combination of an ontological and constructivist approach of scales, our contribution challenges this scalar construction questioning the "locality" of the large ranchers and showing that their role as "local developers" is actually rooted in regional/national/international scales. We then study the most important effect of the antienvironmental grand scalar narrative: its influence on regional and national decision makers. Wellconceived and publicized scalar scenarios are efficient in this context as in many others.
\end{abstract}




\section{Introduction}

During the past two decades, the environmental conflicts have become so important at the global scale that they can appear as a consequence of the rise of an environmental globalization. Within the traditional levels of justification of discourses or actions (Boltansky and Thévenot, 1991), the rise of an "environmental justification" (Lafaye and Thévenot, 1993) can be linked with the "increased role of globally organized management institutions, knowledge systems and monitoring, and coordinated strategies aimed at resource, energy and conservation issues" (Zimmerer, 2006: 1). For environment defenders, financial support, institutional recognition and also scientific legitimization can be reached through networks, institutions and debates that are autonomous from the traditional instances of legitimization such as local power, States or companies (for instance: Mol, 2000).

In the case of natural resource management, it is particularly evident. Indeed, natural resources are becoming more and more limited, and their appropriation for opposing goals such as conservation and exploitation implies conflicts between different kinds of projects over the same territory. But even if the objectives are opposed, the ways in which natural resources are appropriated by the economic and environmental facets of globalization are not very different. Studies on so-called environmental governance show that the appropriation of natural resources for environmental management purposes implies, for the appropriating institution, creating new institutions, scales and networks for conservation purposes, adapting these institutions to existing scales of management of these resources (in particular, but not only, the State scale), linking the different scales to one another through networks (Karkkainen, 2004; Bulkeley, 2005) and, in doing so, creating new scales and territories in order to manage the resources (Bailey and Maresh, 2009; Agrawal et al., 2008; McCarthy, 2005).

The actors concerned by environmental governance did not take long to retaliate. A counter discourse of environmental globalization emerged that seeks to delegitimize environmental discourses arguing that they are an interference from the international level (Rossi, 2001; La Rouche, 2001). They can be described as anti-environmentalist grand scalar narratives: this kind of discourse is based on the meta-narrative language structure (Lyotard, 1979), while it aims at the same time to create homogeneous scalar levels and to oppose these scales one to another - ie the local scale to the international one (Arnauld de Sartre and Taravella, 2009).

The rich and recent debates on the social construction of scales (for a summary, see Neumann, 2009) conducted by scholars in the fields of political economy and politics of scale (Neumann, 2004; Delaney and Leitner, 1997; Agnew, 1994) have insisted that special attention must be given to political issues underlying the construction of scales in the field of environmental studies. Indeed, highly valuable research conducted for over twenty years by geographers on the construction of scales has offered a renewed understanding of environmental issues.

Hence, this paper is a response to the invitation of many political ecologists to explicitly examine scales as objects of theoretical and empirical analysis, to investigate how scales and scalar interrelationships are socially produced through political struggle. We aim to demonstrate that scales, and especially the local scale, are at the same time taken for granted (because there are resources to be appropriated) and appropriated through symbolic and political conflicts by both the environmental and the economic stakeholders in their appropriation quest for the natural resources. In doing so, we acknowledge, as Manson did in this journal (Manson, 2008), that scale is to be apprehended through a continuum between an ontological and a constructivist perspective. The ontological aspect of scale is at the same time the natural resources that are to be appropriated (McCarthy, 2005 shows that every society has to appropriate the natural resources that exist at specific scales) and the political scales that organize the appropriation of reality. The constructivist aspect of scale is, in our case, in the patterns of discourse, political struggle and multilevel networks that allow appropriation of the ontological aspect.

We shall demonstrate, by studying the particular strategy developed by natural resources exploitation-oriented actors regarding natural resource appropriation, that the construction of a grand scalar narrative and the fact of being legitimate at one particular level (in this case, the local one) is a challenge not only for the conservation-oriented but also for the exploitation-oriented stakeholders. This challenge is met through a process which is both ideological and political. In the specific case of 
Amazon natural resource management, the construction by the local bourgeoisie of a narrative which aims to legitimize them at the local scale and to delegitimize the environmental actions as being interferences is crucial. Indeed, a substantial number of studies, since the late 1980s, have clothed the local communities with virtues of environmentalists or ecological noble savages, falling into an "environmental localism trap" (see Abakerli, 2001 for a critique of this perspective; Brandon et al., 1998; Peres and Terborgh, 1995; Browder, 1992; Redford, 1992). On the contrary, large ranchers are often presented as anti-local and anti-environmental actors. However, much research has recently given the voice to self-labeled "local" actors and succumbed to a kind of "development localism trap" (Brown and Purcell, 2005): following the discourse of these protagonists, the situation is described as the struggle between "local" actors of development against "external" environmental groups (Abakerli, 2001; Little, 2001; La Rouche, 2001). But the local development actors such as large ranchers or foresters have been until yet scarcely studied, even if their logics and impacts are well understood (Walker et al., 2009).

If the scope of this contribution is the Brazilian Amazon, our demonstration is based on a case study of conflicting management of natural resources in the Eastern Amazon. In the Terra do Meio ("Middle Land"), region of the Southern Pará state, two visions of the Amazon collide: one defending the pastoralization of territory (conversion of rainforest to pastures) and the other promoting socioenvironmental conservation. The tension between these two opposite poles is characteristic of the contemporary construction of the Brazilian Amazon territory, as noted by most of the authors who place the figure of "territorial conflict" at the center of their analysis (Simmons et al., 2007; Becker 2004; Fearnside, 2001; Théry and Mello 2005). Opposing the creation of a mosaic of protected areas by the Federal government, the large ranchers have developed a mystifying discourse on scales, arguing that the creation of the mosaic follows the campaign of a coalition comprising national and international environmental non-governmental organizations (NGOs). The objective of our article is twofold. First, we report original empirical findings about Amazonian development, particularly analyzing the main characteristics and strategies of large ranchers. Secondly, we demonstrate how current theoretical reflections on the politics of scale can be integrated to analyze environmental struggles, in particular concerning conflicts between stakeholders around the construction and the legitimization of their actions at certain scales.

Our argument is organized in six sections. First, we describe the context of the case study and the research method, the so-called "local" context. We then present the ranchers' discourse on territory management which opposes the "local" cattle raising activity to the "external" interference of the civil society coalition and the Federal government. The following sections bring to light the social construction of this scalar narrative. We begin by questioning the "locality" displayed by ranchers when they describe themselves and then reveal that the impressive progression of livestock activities in the region is actually supported by strong public policies at the regional and national scales respectively. Finally, we show that the weakness of socio-environmental activism organizations at the local scale is the result of the "smothering" strategy followed by the ranchers, which is based on the support they receive from regional and national levels.

\section{Description of the "local" context}

\subsection{The socio-spatial dynamics of Terra do Meio}

The Terra do Meio ("Middle Land") is a forested region of the Brazilian Amazon of some 7.9 millions hectares, nationally recognized as important for the Amazonian biodiversity conservation (MMA, 2001), and located between the Xingu and Iriri rivers (Figure 1). It belongs to the counties of São Félix do Xingu, Altamira and Trairão (only a small part). In recent years the region has seen a sharp rise in deforestation. Indeed, before 1997 , less than 50,000 ha of forest were cleared in the Terra do Meio, but since 2001, 50,000 to 80,000 ha are destroyed annually. Grass species are then sown over 90\% of cleared areas for cattle ranching (Taravella, 2008; Arima et al., 2005; Walker and Moran, 
2000; Sayre, 1999). As in many regions of the Amazon, the pastoral activity of ranchers in the public lands is driving the advance of deforestation, and has two important features. First, the pioneers are not legal owners of the land they have cleared (Brannstrom, 2001), and according to the Brazilian environmental law $-7^{\text {th }}$ Normative Instruction on April $27^{\text {th }}$, 1999 - ranchers have not received prior legal authorization for clearing issued by the federal body responsible for the management of renewable natural resources and environment. In other words, the ranches that have flourished in the Terra do Meio since the late 1990s are illegal.

Figure 1 - Location of the Terra do Meio

Because of the eight indigenous lands that surround the Terra do Meio, pioneers have entered the Terra do Meio only from the "hole" of this protective shell located in the south-eastern part of the region (Figure 2). It is here that the town of São Félix do Xingu was established by the traditional Amazonian population before becoming an important platform for the conquest of the western forested territory of the South Pará region (Nunes, 1998; Schmink and Wood, 1992). Since the early 2000s São Félix do Xingu city has become the center-base for the regional livestock economy. Most of the social, political and economic local life revolves around pioneer activities and the cattle sector (Castro et al., 2002).

Figure 2 - Land use in the Terra do Meio

Note - The figure represents the territorial colonization in early 2005, i.e. before the creation of the national park and the ecological station in the Terra do Meio

The domination of the cattle sector - and its actors - in São Félix do Xingu city and in the Terra do Meio, has caused contestation of the pioneer frontier's advance in a northern part of the Pará state. To put an end to the deforestation and the violent expulsion of "traditional people" (ribeirinhos) that have lived for decades on the bank of the river, several socio-environmental associations located along the Transamazon Highway and concentrated in Altamira town (see Figure 2) have engaged in collective action that quickly received support from national and international NGOs (Campos and Nepstad, 2006). The meeting of the coalition's demands with the Federal Government's agenda led to the progressive creation between 2004 and 2008 of a mosaic of protected areas ${ }^{1}$ - managed more or less strictly - that covers more than $90 \%$ of the Terra do Meio (Figure 3 ).

Figure 3 - The mosaic of protected areas of the Terra do Meio

Due to their illegal clearing activities, ranchers have been forced to abandon their occupations located in the stricter protected areas - an Ecological Station and a National Park that cover about $40 \%$ of the Terra do Meio - without hope of compensation. Federal decrees of expulsion have been issued against large ranchers that refuse to abandon their ranches.

\subsection{Research method}

Over recent decades, environmental issues have assumed a growing importance in political agendas. Despite the public commitments made and the ambitious management systems set up, examples pervasively show that processes causing serious environmental degradation are out of control. Analyzing and assessing the coherence and effectiveness of actions in the light of environmental commitments must be, more than ever, a central issue for environmental studies (Mermet et al., 2005). Based on strategic approaches of organizational sociology and strategic management, Strategic Environmental Management Analysis (SEMA) addresses this challenge. SEMA specifically analyzes the discords arising from conflicting uses of territories or natural resources (Mermet, 1992). Territory management is approached as the result of interactions between opposed groups, located at various scales (from local to international). Understanding this interaction

\footnotetext{
${ }^{1}$ Protected areas in Brazil are classified into two categories: Integral Conservation Unit (UCI) and Unit for Sustainable Use (UCS). The first gathers protected areas where only indirect uses of natural resources are allowed, like a National Park or Ecological Station. The second covers protected areas that permit direct "sustainable" use of natural resources, like an Environmental Protection Area, National Forest or Extractive Reserve.
} 
in the Terra do Meio required two in-depth inquiries, one with the pioneers and another with the members of the collective action for conservation.

For the first inquiry conducted over a period of ten months, we combined participant observations undertaken in the Terra do Meio region and São Félix do Xingu town, and semistructured interviews with key informants of the pioneer frontier. Based on the ethno-definitions commonly used by pioneers (Barth, 1969), we identified three local groups: small farmers (colonos), middle-size ranchers (fazendeirinhos) and large ranchers (fazendeiros). We interviewed 128 colonos, 35 fazendeirinhos and 71 fazendeiros obtaining in each case qualitative data (on their migration history, their relationships with others actors, their vision of the territory) and quantitative data (through a questionnaire on their property, ranch, livestock, home).

Given their central role in the local economy and in the socio-political local system, we dedicate special attention to the large ranchers. According to the informants, this sample represents between $40 \%$ and $60 \%$ of the large ranchers' group. As a socio-anthropological inquiry (Becker, 1998), we used the snowball sampling method, following the recommendations and introductions provided by the actors themselves. More than $75 \%$ of the interviews used in this paper were conducted either immediately after the hearing organized in São Félix do Xingu (December 2004), where the national and regional environmental authorities presented the Ecological Station and the National Park projects, or in the following 8 months. Questions asked were: "What do you think about these projects?", "What do you think about the hearing?", "What would be the consequences for the region?" All the people interviewed were informed of the purpose of the study and gave their free prior consent for faithful transcription of their words, analysis and if needed quotation.

The direct and indirect incentives from the regional and national level were addressed thanks to the analysis of official documents (laws, decrees, budgets, agricultural and livestock politics, governmental priorities and strategies, official discourses). We conducted interviews with governmental and non-governmental spokesmen of the Brazil cattle sector, and with researchers working on this field.

The inquiry on the coalition for the Terra do Meio conservation combined, over a period of five months: participant observations of one of the Transamazon Highway social movements involved in the coalition and twenty-two semi-structured interviews with key informants of local, national and international organizations. Questions frequently asked were: "What do you do in the Terra do Meio?", "How did your organization start working in Terra do Meio?", "Who are your main local, regional, national and international partners?", "Could you explain the process leading to the creation of the protected areas", and "How do you see the future of the region?" Fifteen semi-structured interviews were also conducted with members and spokesmen of socio-environmental associations and syndicates located in São Félix do Xingu in order to understand their actions, their current situation and the reason why they did not ally with the coalition for the conservation of the Terra do Meio.

\section{The narrative of local vs. national/international scales}

In response to the rumors of protected areas creation and then to the official speeches of creating them in the Terra do Meio, the large ranchers of the region organized themselves into the Associação agropastoral dos produtores das terras do meio - XINGURI association - in order to be heard. The association is exclusively composed of large ranchers that occupy an area in the Terra do Meio. As the president of the association explained:

" $[t]$ he objective of our association is to organize ourselves in order to fight for our rights. We want to show the government and the public that we exist. We want to be visible. In order to do that we think we need an official status to defend ourselves against the governmental projects. [...] The association was created because of the reserves, because we needed to react."

Indeed the ranchers reacted effectively and quickly, since the association was created only a few weeks after the publication of the first official documents - the Planning Project of the Pará state 
(Estado do Pará, 2004) - mentioning the protected areas. Members and spokesmen of the XINGURI association are the main voices against the creation of protected areas. To oppose the project and the federal decree of creation, their discourse articulates two main components: the "local development" they are responsible for and the "environmental interference" coming from the national/international scales. Doing so, they are building the divide between the "constructivist aspect" of scale in order to legitimize their "ontological" (and economical) appropriation of the territory (Manson, 2008).

\subsection{The "local development" by the livestock economy}

Local development is a clear goal of the XINGURI association whose objective according to their founding document is "to contribute to the economic and social development of the local community and the region" (XINGURI, 2003). The idea of ranchers in the Terra do Meio as "local developers" is even more visible in the speech made by of one of the spokesmen of the XINGURI association during the hearing for the creation of the national park and the ecological station:

"We aren't pioneers by malice or dishonesty even if we are categorized all day [in the national and international press] as bandits or invaders. We are workers who need to work and survive. Here, we are alone. Governments do nothing. We have opened the roads, invested in the region, grown cattle. We have created the region [...] We are the developers of the region. You can ask anyone here. Everybody here is benefiting from our work. We are not only working for ourselves. We are working for all the people there, for the region and for our Brazil."

The large ranchers' argument is clear: they are the main agents of development in the local community. Pará and Federal governments are not differentiated, and both directly accused. The ranchers use this discourse to turn upside down the frequent accusations, in national and regional press, that denounce their illegal practices and their violent behavior. Now the guilty is the "absent State" that obliged them to develop the region by their own limited means, in their traditional way. In Belém, capital of the Pará, this vision of the local large rancher is also defended by the president of the Federation of the Agriculture and Livestock of the state of Pará (FAEPA).

Interviewer (I): You are aware of the important environmental and social impacts of the pioneer frontier progression, especially the livestock activity in the Terra do Meio, aren't you? What do you think about these problems?

Respondent (R): You have to understand the history of the colonization of the region and the history of the ranching activity. In fact, we have to make a distinction between the first pioneers, people who were more courageous adventurers than responsible producers, and the nowadays entrepreneurial ranchers that are in the region. Now, they are real corporate managers who know their business and work for the region [...]

I: Alright, but what is exactly the difference between the two?

R: The old pioneers were making livestock without understanding the place, their environment, without thinking of a better production system. They were kind of adventurers. [...] So these men were replaced by the new entrepreneurs. They are totally different. They know how to produce, how to manage their property, their pasture, their cattle. They are very responsible. They are not working only for themselves, they offer a lot of job opportunities for the region. They are the main source of economic activity. Have you seen the recent statistics about the Pará GDP? [...]. They are the region's vector of development.

Large ranchers' portrayal of themselves is unambiguous: they are responsible producers that have taken charge of the local development through their economic dynamism and their entrepreneur spirit.

But their local role is not merely economic (Velasquez et al., 2006). Small farmers and middlesize ranchers usually express profound gratitude towards the fazendeiros and describe them as "the rescuers of the region" or "those who are doing something when the government is doing nothing". The colonos are undoubtedly thankful for the massive arrival of ranchers in the region since 2000, because "they have brought a lot of calves", "they have opened the road", "they have made pastures everywhere" and "they have offered jobs". As a fazendeirinho explains: "Now, thanks them we are in 
paradise. They have brought development to the region[...] Without them we would not still be here today". Small farmers show pride to be working for ranchers, referring to them as "our rancher" or "the rancher of our region". The first step of their grand scalar narrative, their local relegitimation, is reached through this argument. The second step refers to the delegitimization of the environmental stakeholders.

\subsection{The "national/international imposition" of protected areas}

On February 2005, the sudden and violent murder of Dorothy Stang, an American nun who had worked for twenty years among small farmers of the Transamazon Highway, accelerated the already launched process of the protected areas' creation - the national park and the ecological station were decreed less than two weeks after the assassination. To revoke the creation of the protected areas the XINGURI association registered two complaints with the Supreme Federal court (STF - Supreme Tribunal Federal). The Official Journal of the STF (n ${ }^{\circ} 98$ of 24.05.2005) reports the first complaint (lawsuit $n^{\circ} 25.246$ ) in these terms:

"f) Attack on national sovereignty, since the administrative process [of the creation of protected areas] used data that was collected, analyzed and finalized in record time by international organisations, mainly because of international pressure resulting from the death of missionary Dorothy Stang: beginning of the administrative process (November $18^{\text {th }}, 2004$ ), death of the nun (February $\left.12^{\text {th }}, 2005\right)$ and publication of the Decree (February $\left.17^{\text {th }}, 2005\right)$, clearly demonstrating the "supremacy of international power over the national interest" (1.27)."

The Official Journal of STF $\mathrm{n}^{\circ} 112$ of 14.06 .2005 reports the second lawsuit $\left(\mathrm{n}^{\circ} 25.348\right)$ as follows: "But the plaintiff does not stop there, alleging that the decree mentioned above was also heavily influenced by the presence of international organisations" and announcing that "the administrative process was disturbed by the international commotion" (1. 42)."

The two complaints offer the same interpretation of the federal action for conserving the Terra do Meio: the international level put pressure on the national level, which then had to impose the protected areas on the local level. Moreover, according to the large ranchers, the national level would even be an accomplice of the international level. This argument is take up again and even précised in the pamphlet entitled "Manifesto" written and broadcasted by members of XINGURI just after the creation of the national park and the ecological station:

"Fourth: When an institute that claims to be for the "environment" is using public resources to promote the dislocation of the entire production process installed in a region, we must ask if it is really in charge of defending the interests of the Brazilians, or rather, as practice has shown, is under the direct influence of "NGOs", "international pharmaceutical groups", "pirates of biodiversity" or "mining companies"; [...]

Ninth: We make public that our pioneering activity, adventurers of the Amazon, is a cultural quality that will never be inhibited by governmental decrees alienated from the reality of our Brazil;" (XINGURI, 2005b).

In many interviews, large ranchers place local actors against the associations at the national and international level. Contrary to the former, the latter would not be aware of the "reality of the field", as one of them explained:

"These guys of the ministries or NGOs are working in nice offices with air conditioning. They know nothing about the reality of the "environment" or the Amazon rainforest. They love environment on paper. I would like to see one of them one day doing what we have done here. [...] You, you know what life is like here. You know what the winter is [rainy season] when you have to spend one day running twenty kilometers. [...] That is the reality of the region. It is difficult to live here. There is nothing beautiful about living in the middle of the forest. What people need is development."

The Grand Narrative (Lyotard, 1979) used by large ranchers in the two complaints to the Supreme Federal court and in their manifesto provides three elements for our analysis. First it offers a narrative about scales, and more precisely distinguishes two of them: the local level and the national/international level. The regional scale (of the Pará state) is rarely mentioned. Second, it 
assigns relative power and legitimacy to the different scales. The local scale is powerless but legitimate, while the national/international scale is powerful and illegitimate. Third, it places the different actors implicated in the management of the natural resources of the Terra do Meio in the different scales (for an in-depth analysis, see Arnauld de Sartre and Taravella, 2009, Arnauld de Sartre and Berdoulay, 2011).

The colonos and fazendeirinhos interviewed adopted a less structured and accusatory discourse on environmentalists, but nevertheless left little doubt about their local belonging. As a colono states:

"When we arrived here there was not a word on the park issue. I had never heard about that before. And one day, they all came here, showed us pictures, and explained to us what they decided to do. [...] They did not ask us what we wanted. The local population was not consulted. Apparently, they decided that between them. Here, we have to accept".

Colonos and fazendeirinhos, who benefit directly and indirectly from the pastoralization of the Terra do Meio promoted by the fazendeiros, share the large ranchers' vision about the opposition: local/development vs. international/environment.

\subsection{The Grand Narrative effect}

The Terra do Meio large ranchers' discourse is not confined to the local scale. As demonstrated above, it has acquired a place in the Pará state capital and has ascended to the highest level of the Brazilian judiciary system. The words of the president of the Environmental National Commission of the National Confederation of Agriculture and Livestock $(\mathrm{CNA})^{2}$, released in Agence CNA 07/12/2006, showed the vertical organization of the large ranchers, their ability to transmit and produce a coherent narrative from local to national level, and their capacity to use the narrative as a clear means to an end:

Journalist: How do you intend to defend the rural farmer in
environmental issues?

CNA: The defence of the farmer, our duty, will be performed on different fronts, starting with the proper judiciary defence, a field where we need improvement. We need to prepare ourselves for the confrontations, bringing together the important elements that will help us to be stronger, from the institutions located in the counties, then at the level of the federations present in the [federal] states, and finally here at the level of the highest courts, in order to try to reverse the process of destruction and penalization of the farmer. Another important battleground is the legislative field. We already work in the National Congress, with an expressive force. We have many members and senators who are part of the famous "rural group" that help us a lot. The CNA already performed an in-depth work of parliamentary assistance. And we hope to increase it even more.

The "rural group" ("bancada ruralista") is actually one of the most powerful lobbies of the Brazilian democracy. The "parliamentary assistance" and the work done in the ministries allow the large ranchers' narrative to influence national policies. On the one hand, a set of public assistance policies have been designed and implemented year after year to support the pastoralization of the Amazon (Arima and Verissimo, 2002; Laurance et al. 2001). On the other hand, the narrative used at the different levels of power deeply influenced the creation of the mosaic of protected areas in the Terra do Meio. Two aspects need to be highlighted. First, as a response to the unexpected local contestation during the hearing of December 2004, the authorities agreed to consider an "alternative delimitation project" (XINGURI, 2005a) of the ecological station and national park designed by the local population. The federal and regional environmental institutions agreed to meet a delegation composed of 4 farmers, all members of XINGURI association, accompanied by 3 deputies. As a result of this advocacy work, the ecological station and the park, both created in February 2005, integrated part of the local demands. The final delimitation differs substantially (in surface and shape) from the original project conceived by the Federal environmental administration. Second, a few weeks after the creation of these protected areas, the Ministry of Environment organized a special meeting in São

\footnotetext{
${ }^{2}$ The CNA gathers the agriculture and livestock federations existing in each federal state, like the FAEPA in the Pará, which in turn encompasses the agriculture and livestock associations based in the Brazilian counties.
} 
Félix do Xingu with some of the pioneers' representatives, to discuss the compensation that would be offered to them. The delegation, $70 \%$ of which were XINGURI association members, advocated for the maintenance of livestock farming in the region and the regularization of the ranchers' occupation in the Terra do Meio. After several audiences with the governor of Pará, the government of Pará finally created in 2005 two protected areas in the Terra do Meio (APA Triunfo do Xingu and FLOTA Iriri, see figure 3). Both protected areas allow direct use of natural resources, aim at regularizing the occupation of the territory by the pioneers, and facilitate the development of the productive activities (livestock/forestry). As a large rancher stated confidently: "for us, the acronym "APA" will not stand for "Environmental Protection Area" but for "Area for Agricultural Production"." The mosaic of protected areas was strongly influenced by the large ranchers' resistance.

The following sections put into perspective the scalar narrative proposed by the fazendeiros, in order to deconstruct it. First we question the "locality" expressed by ranchers when they describe themselves. Second, we show that the locally labeled and flourishing livestock economy relies on strong incentives coming from the upper scales. Finally, we argue that this strong vertical support to the cattle sector is precisely the one responsible for the absence of socio-environmental actors in São Félix do Xingu, as denounced by the ranchers.

\section{Large ranchers: a very distant locality}

The location of the "homes" and households of large ranchers provide a fruitful insight to their claimed locality. At the present time, more than $95 \%$ of the large ranchers interviewed are not living in the Terra do Meio. On average, they spend about four weeks a year in their ranch in the Terra do Meio. They travel up to ten times to their ranch, and more than $80 \%$ of their trips are realized during the wet season (from March to September). Figure 3 provides information on the location of their "homes" which actually are not situated in the Terra do Meio. A considerable number of the large ranchers' "homes" (44\%) are even located outside the Pará state. The homes in the Pará state are mostly located far from the Terra do Meio region (36\%). Only 17\% of the large ranchers interviewed have a house in São Félix do Xingu, the closest town to the Terra do Meio. The members of the XINGURI association also have this distant relationship with the Terra do Meio. Neither the president, the vice-president, the treasurer, nor the secretary live in the Terra do Meio. The association itself was registered officially in Tucumã county (150 km from the Terra do Meio).

Figure 3 - Information on the location of the ranchers" "homes"

More than $50 \%$ of the ranchers interviewed declare having another "land" or "property" outside the Terra do Meio. For them, the ranch in the Terra do Meio is a prosperous business. The investment returns in large scale cattle ranching are 35\% higher in the Amazon than in the Centre-South region of Brazil thanks to: climatic advantage - exceptional tropical weather with no cold season auspicious to fast grass growing, easy access to public land, and low land prices (Arima et al. 2005). Through these incentives the livestock economy in the region is extremely attractive for the "entrepreneur" rancher type. Even if the investment of large ranchers results in local job opportunities, three elements need to be stressed. First, the extensive cattle production systems developed by the ranchers in the Terra do Meio have a very low ratio of local employment compared to other agro-pastoral or industrial activities (Schneider et al., 2000). Second, in many cases, ranchers bring their own trustworthy workers to the region. These workers can either watch over the ranch all year round or accompany the rancher during his visits. Given their rare presence on the ranch and their distance from it, the large ranchers have to rely on employees they know and trust. Third, part of the profits from the livestock activity in the Terra do Meio is exported. Indeed, the ranchers use profits to invest in new ranches in other regions, in the ranch they have outside the Terra do Meio or in their own household (Taravella, 2008). 


\section{The regional public policy drivers of the "local" livestock success}

\subsection{The repeated promises of public land distribution}

More than $60 \%$ of the ranchers interviewed declare that the promises made by the Pará state Land Institute (Instituto de Terras do Pará - ITERPA) have strongly influenced their plan to invest in the region. All the informants refer to two meetings organized by the former director of the ITERPA in 1993 (or 1994) and in 2001. Since no official record of the meetings has been found, we rely on the triangulation of the statements obtained from the participants.

During the first meeting, the director of the ITERPA specified his will to "put the land situation in order" in the Terra do Meio so as to "facilitate the legal appropriation of the free lands for migrants". He declared his aim to promote a "clean occupation of the space". For that purpose the ITERPA would have been engaged in the official dividing of the public land to regularize and settle large landholders. As a large rancher explained:

"As usual at that time, he said that the selling of the land would benefit first the actual occupants, if they demonstrated their will and capacity to properly develop the land. [...] This means a sufficient clearing, some alqueires [surface units of 4.8 ha] of pasture, the construction of a house, maybe a cowshed, and livestock, obviously."

During the 2001 meeting, the director of the ITERPA first apologized for not having kept his promises before, and made new promises of land regularization for the occupants. Following the testimonies of the ranchers, he explained that the actual occupant would receive economic incentives, paying only $10 \%$ of the price offered to others. His discourse about promoting land occupation by promises of future land regularization is nothing new or exceptional in the Brazilian Amazon: Fernandes (1999) describes similar dynamics during the 1970s, while Léna (1999) and Fearnside (2001) consider that land-tenure regularization is one of the key factors of current deforestation in the Amazon. The persistence of such promises, their role in the contemporary pioneer strategy of the ranchers and their consequence on pioneer frontier progress is striking.

\subsection{The fiscal incentives}

The Brazilian government has supported Amazonian colonization through fiscal incentives for a long time: "Throughout the Brazilian Amazon, the expansion of livestock production was intimately linked to the expansion of roads and a variety of credits ranging from fiscal incentives to subsidized agricultural loans" (Hecht and Cockburn, 1990: 168). The public fiscal incentives that supported the deforestation of the Amazon supposedly ended in the mid 1980s (Costa, 1998). But the support given by the Pará state to the pastoralization is salient when looking closely at the changes in the "Tax on Operations Concerning Circulation of Goods and on Interstate and Inter-county Transport and Communication Services" (ICMS) levied by the state since $1988^{3}$ (see also Walker et al., 2009).

Constitutionally, the ICMS is a tax that only states can collect. As illustrated in Figure 4, the changing tax rates experienced a double evolution. On the one hand, tax exemptions gradually reduced the number of transactions subjected to the ICMS: 3 between 1989 and 1992 (between producers, between producers and slaughterhouses, and between slaughterhouses and wholesalers); 2 between 1992 and 1995 (between producers and slaughterhouses, and between slaughterhouses and wholesalers); and 1 after 1995 (between slaughterhouses and wholesalers). On the other hand, the tax rate has been progressively reduced. For example between slaughterhouses and wholesalers the tax was of $17 \%$ in $1989,7 \%$ in $1993,2 \%$ in $1995,7 \%$ in $1996,4 \%$ and then $1.8 \%$ in 1999.

Figure 4 - Evolution of the ICMS for cattle in Pará state

\footnotetext{
${ }^{3}$ We focus on the "internal" ICMS applied to cattle, i.e. levied for circulation and services that take place between two municípios of the Pará, but the same demonstration could be made with the "external" ICMS on cattle.
} 
This evolution is mainly based on the fact that livestock has become a "priority productive activity" (Law No. 5.943/96 altered by Law No. 6.489/02). This policy is described by the government as "one of the main instruments of the state of Pará to promote the attraction of private investment, through the establishment, modernization and diversification of productive enterprises." Tax incentives provided under the Act are intended to consolidate a "modern and competitive economic development" (Article 2). The agricultural sector appears to be the first to benefit from this assistance (Article 3) for the "interest of the strategic development of the state." The granting of this aid, as we verified in conversations with ranchers, plays a crucial role in the migration strategies of these capitalist agents. Tax incentives have then become an important issue for the election, launching a real fiscal battle, the so-called "war of ICMS" between states struggling to propose the lowest rate for investors (Piancastelli and Perobelli, 1996).

\section{The national/international public policy drivers of the "local" livestock success}

At the national/international scale, the large ranchers benefit from three kinds of incentives: technical and scientific, financial and diplomatic.

\subsection{The technical and scientific input}

In the context of the "green revolution" promoted by industrialized countries to stimulate intensive production in developing countries, the Brazilian Center for Agricultural Research (EMBRAPA) was born in 1972. As the Brazilian Minister of Agriculture at the time, Luiz Felipe Cirne Lima recently explained, the institution was in charge of making "viable the modernization and growth of agriculture through technological research, knowledge transfer to rural producers and the advance of agricultural frontiers" (Cirne Lima, 2005, p. 28). Following Costa (1998), we underline the important role played by research on livestock in the EMBRAPA center of the Eastern Amazon. According to the author, animal husbandry accounted for $3 \%$ of publications until the mid-seventies, $26 \%$ during the second half of the seventies, $22 \%$ between 1980 and 1984, 56\% between 1985 and 1989 and $41 \%$ during the first half of the 1990s. Making the livestock investment in the Amazon more profitable, the public federal research irrecusably plays an indirect role in the promotion of livestock in the region, and then in the advance of the pioneer frontier (Kaimowitz and Angelsen, 1999; Cattaneo, 2005). Some authors even recognize their direct responsibility in the spread of pasture in the Amazon (Veiga et al., 2003). Moreover, research about livestock has frequently received international support through long-term foreign cooperation.

\subsection{The financial support}

Nowadays, Brazilian agribusiness accounts for around one quarter of country's Gross Domestic Product (GDP) and one third of its jobs. The importance of the agriculture and food industry sector is not only due to the quantity of land available, the good weather conditions or the improvement of productive technologies. Contrary to the speeches held by Brazilian diplomats at the World Trade Organization (WTO) advocating less state intervention in the economy, the federal government continues to renew financial support to the agriculture sector, year after year. The Agricultural and Livestock Plan 2005/2006 (Brasil 2005), which enjoys a budget of some fifteen billion dollars, reveals the many ways the federal government supports its exporting industry through guaranteed prices for food crops, storage policy, subsidized credits, renegotiation of bank debts contracted by producers, and so on.

In the particular case of the Terra do Meio, federal support takes the form of subsidized credits allocated by the Constitutional Fund for the North (Fundo Constitucional de Financiamento do Norte FNO) and granted to several ranches of the region. Moreover, as Taravella (2008) demonstrated, the socioeconomic ties between large and small farmers in the southern Pará are exceptionally strong. An actual informal organization underlies the progression of the livestock activities in the region. Due to this systemic relationship built and maintained between small farmers and large ranchers, the financial policy applied directly to the former benefits indirectly to the latter. For example, financial incentives 
for animal acquisition offered to small farmers will end up in the hands of large ranchers since they systematically buy their livestock in nearby ranches (Taravella, $2008: 414-415$ ).

\subsection{The diplomatic help}

The "hamburger connection" hypothesis was proposed to describe the strong connection between: beef consumption in developed countries, livestock development in Central America (Myers, 1981) or Brazil (Kaimowitz et al., 2004), and the deforestation of the Amazon rainforest. According to this hypothesis, beef exportation from South American countries to international markets would be one of the major drivers of the pastoralization of the Amazon region.

Accordingly, the current multiplication of diplomatic efforts undertaken by the Federal government to open new markets for the Brazilian agricultural products represents an efficient support to livestock development in the Terra do Meio. Indeed, if the policy assessment pursued by President Luiz Inácio Lula da Silva provokes many polarized debates, most analysts agree that the success of the government's foreign policy is due to the innovations and updates of diplomatic practices (Alden and Vieira, 2005). This new tendency arises from a strong pragmatism, primarily driven by commercial activism leading the Brazilian president to develop new trade agreements and expand existing ones. This "new trade geography" politics defended by the President (Brésil, 2006), is still embodied by the diplomatic offensives against agricultural protectionism implemented by northern countries. Indeed, Brazil played a proactive role in the creation of the "Group of the 20" at the World Trade Organization meeting in Cancun in October 2003.

Our study of the public incentives directly or indirectly received by the large ranchers of the Terra do Meio show that their proposal of a local scale devoted to development of the livestock economy and a national/international scale exterior to this issue is not appropriate. The locality of the large ranchers can be challenged, since not only do they not actually live in the region, but the role they play locally is the result of several incentives coming from the regional, national and international levels. What is more, we argue that this multilevel support to ranchers has caused the absence or the weakness of a local socio-environmental voice of dissent towards the pastoralization of the Terra do Meio.

\section{The "smothering" of local dissent}

The regional and national incentives assigned to the livestock sector in the Amazon have allowed the ranchers - as a central actor of this sector - to become a key economic actor of this region. This economic importance has given them a powerful social and symbolic influence in many remote Amazonian municípios. In São Félix do Xingu, a large rancher member of the XINGURI association, was elected mayor both in 1997 and 2001. His presence in government functions, in turn, opens the door to an enhanced socioeconomic, symbolic and political local domination of the large ranchers and to the exclusion of alternative local voices.

The ranchers have converted their economic capital (result of the vertical supports received from the regional and national level) into social and symbolic capital (Bourdieu, 1994). They have transformed it into political capital - defined as "ensuring to its holders a form of private ownership of public goods and services" (Bourdieu 1994: 33) allowing them the patrimonialization of local collective resources - which in turn has enhanced their economic, social and symbolic local domination.

Antônio Paulino da Silva arrived in São Félix do Xingu in 1984. Born in the Goiás state, he made his fortune in Tocantins through cattle ranching and political activities. As he explains, upon his arrival on the banks of the Xingu, he was driven by a single goal: to conquer the local political power in order to "bring development to São Félix". In his first campaign in 1992, he suffered a defeat. The reason he gives is eloquent: "the ranchers were very few at that time, with only a small influence [...] the local economy was totally dominated by the old patrões. They were still at the center of the economy. They were involved in everything with their archaic political assistance".

But four years later, for the next election, the situation had changed. Boosted by the regional and national public aid and the coming of migrants, the livestock economy became the motor for 
development in southern Pará. As in the classic development of the Amazonian territories following the "boom and bust" model (Schneider et al., 2000), one unique sector "explodes" and becomes the pillar of the local socioeconomic development. In the mid-1990s, the livestock sector became this pillar: the cattle numbers grew from 100,000 in the early 1990s to 1.3 million in early 2000s (GEOMA, 2005). The economic importance of the fazendeiros has made them socially important since a significant part of the local population depends directly and indirectly on their activity (Taravella, 2008). In the context of the Amazonian pioneer frontier this socioeconomic domination frequently takes the shape of the "oppressive paternalism" (Geffray, 1995; Esterci, 1996). Their economic and symbolic domination are inseparable, well described by the concept of paternalism ${ }^{4}$. Moreover, both the possession of an extended livestock and the ranchers' activity have a very high social value in Brazil (Veiga et al., 2004). Using their economic, social and symbolic capital, the large ranchers succeeded in electing "their" candidate as mayor of São Félix do Xingu in 1997 and in 2001. This political victory was at the same time the consequence of the ranchers' acquired influence, and the milestone of their domination of local politics from 1997 to 2005.

The so-called "prefeitura of the ranchers" massively invested in infrastructure (opening of new roads, bridge construction), making new parts of the county accessible to ranchers and connecting these new territories with the national/international livestock market. Their actions followed the pattern of the "development under the livestock leg" which took place at the Amazonian scale during the dictatorship period (from 1964 to 1985) (Santiago 1972; Hecht, 1993). In order to facilitate the acquisition of land, a temporary ITERPA office was opened in the region thanks to the personal and political relationships of the local political leaders. The creation in 2000 of the Syndicate of Rural Producers (SPR-SFX) was encouraged by the mayor, in order to defend the interest of the capitalized ranchers. For the first president of the syndicate, the SPR was "a kind of annex of the town hall. We were aware of everything. [...] We were in charge of the important issues related to agriculture and livestock". To impose its territory project, the local government implemented an efficient strategy that weakened the local dissenters: socio-environmental grassroots groups in favor of forest conservation and the small farmers union that promoted agriculture diversification (in order to reduce the dependence of small farmers on livestock). Both indeed aimed at jeopardizing the livestock extension in the region.

When the "prefeitura of the ranchers" took up the political rein, the local socio-environmental movement -strongly supported by the progressive wing of the Catholic Church, influenced by the teologia da libertação ("theology of freedom")- was as powerful as elsewhere in the region (Souza, 2006; Castellanet and Jordan, 2002). However, six years later, the local peasant associations and socio-environmental grassroots groups were, according to one of its leaders, "totally inactive". To explain this progressive dismantling, former leaders denounce the "smothering" they suffered when the new elected "prefeitura of the ranchers" supported the creation of a multitude of local associations, putting people whom they trusted at their heads. This operation not only reduced the financial support given to dissent groups for the sake of pluralism, but also directly supported civil society groups that defended ranchers' politics. Moreover, as one representative of the small farmers union explained: "It was a way for them [local government] to gain more power based on the civil society and to divide the population. That's the way they have managed to invade our syndicate." Indeed, supporting the rise of civil society leaders who shared their vision and using their patronage network, the large ranchers managed to "infiltrate" the small farmers union. Since the year 2000, they have used this strategy to paralyze the association, as an informant explained: "from 1999 to 2001, the union belonged to them. They obviously did nothing. They left it to rot." Consequently, the collapse of the small farmers union

${ }^{4}$ According to Peixoto (1996, p. 254) "paternalism as a form of personalization of authority may jointly sustain economic and political controls. The "paternal relationship" seizes the subaltern party's autonomy by softening the exploitation. Such a relationship builds ties of loyalty and indebtedness, creating a circuit in which the beneficiary is obligated to return the favor. The maintenance of this relationship requires the dominated party to be in lacking, so that the dominating party can distribute favors and benefits, and thus establish an ideology of protection". 
left more power and influence for the associations they sponsored and supported, which in turn allowed the prefeitura to strengthen and broaden the capillarity of their patronage and clientelist network.

To explain the local socio-environmental activism's weakness, one of the former leaders drew the following conclusion:

"The only power here is that of the prefeitura. We can't oppose it. It is the source of everything, it has its hand on everything. [...] The association is far too timid. But it has no choice. It's just like the others [associations]. It seeks to negotiate, to find a way to act without opposing the prefeito directly because it is the only resource here. If you oppose or make too much noise, you'll be cut. It has that strength. [...] The only way for us is to cling to a federal program, an exterior aid".

These words are considered here as an example of the "jumping scales" notion, developed by Smith (1993). This political strategy, used by marginalized groups who do not benefit from the present scalar arrangements, aims to circumvent and challenge the present scale structure.

\section{Conclusion}

Both the proposal for and the official creation of the protected areas in the Easter Amazon triggered a set of discourses. Faced with the threat of losing the lands they were occupying, the settlers in Terra do Meio immediately conceived and publicized an elaborated scalar scenario which can be deconstructed bringing in the theorization of scale by Manson (2008). Their Grand Scalar Narrative permitted the large ranchers to legitimize themselves as the "local developers" of the region, concealing the illegality of their practices, their local absence and their strong dependence on regional, national and international inputs: they create a constructed scale which aims to legitimize them and, at the same time, their discourse delegitimized their opponents, whom were favorable to the protected areas. The fazendeiros criticize environmentalists for being absent at the local scale, while they are precisely the ones responsible for this absence, thanks to the strategic use of their socio-economic and symbolic powers in São Félix do Xingu. Doing so, they reinforce their appropriation of the ontological scale, ie the territory of the Terra do Meio. Indeed, the effect of the Grand Scalar Narrative is impressive. Backed by their supporters, the large ranchers managed to modify the limits of the strictest protected areas and caused the creation of "compensation" protected areas that allow them direct use of the natural resources, regularizing their use of the territory.

The constructed dimension of scales and power of the large ranchers, i.e. the scalar levels at and from which their networks take and exercise their power, is hidden by their discourse on scales (constructivist dimension) which finds legitimacy in beliefs shared with the population. Our analysis, which differentiates these two scalar dimensions, is necessary in order to detect and to delimitate the Grand Scalar Narrative, to understand the reasons behind it, to identify its effects, and also to deconstruct it. But the impact of this discourse, which mitigated the protected areas' local impacts and even helped ranchers to reach their own goals, was revealed to be powerful. Indeed, even if this construction of reality based on a scalar organization is not coherent with the ranchers' different levels of power, this discourse delegitimized environmental policies and allowed the ranchers to receive compensation.

Compared to small farmers, large Amazonian ranchers have been scarcely studied (although see Walker et al., 2009; Arima et al., 2005; Simmons et al., 2007). Most of the time, these influential actors only appear in the background. They are frequently portrayed roughly as the "villains" of the region. They are mostly identified as the ones responsible for the violence perpetrated against colonos in the struggle for land. Our contribution helps to enrich the understanding of these protagonists. Those actors are not the "country bumpkin" who work day and night in the middle of their livestock, alone in the interior. On the contrary, they appear to be highly articulate actors, able to produce, defend and broadcast an elaborated discourse that influences decision makers at a local, regional and even national level. Today, their field of action is as much the ministries in Brasília as the pasture of the Amazonian pioneer frontiers, their partners are as much the federal or regional deputies as the local cow dealer. Moreover, they demonstrate a real capacity to transform one form of power into another (social, economic, symbolic, political), reinforcing their domination of the local scale. Further research 
should complete this Amazonian actors' portrait, based on thick descriptions and qualitative approaches, in order to outline their different clans, social organization, rituals, beliefs, and their culture. This is what allowed the fazendeiros to build such a grand scalar narrative, giving birth to a 'scale battle'. Do the environmentalists have the capacity to build a counter scalar narrative at a local level? Even if the environmentalists' discourses often place the emphasis on the local scale, the fazendeiros' grand scalar narrative shows that the legitimacy of environmentalists' actions is not recognized. For environmentalists to gain legitimacy, they will have to the narrative sphere at the local level. 


\section{References}

Abakerli S., 2001. A critique of development and conservation policies in environmentally sensitive regions in Brazil. Geoforum, 32 (4), 551-565.

Alden, C., Vieira, M. 2005. The new diplomacy of the South: South Africa, Brazil, India and trilateralism. Third World Quarterly 26(7) : 1077-1095(19).

Agrawal A., Chhatre A., Hardin R., 2008. Changing Governance of the World's Forests. Science, 320, $1460-1462$.

Agnew, J., 1994. The territorial trap: The geographical assumptions of international relations theory. Review of International Political Economy 1 (1), 53-80.

Arima, E., Barreto, P., Brito, M., 2005. Pecuária na Amazônia: tendências e implicações para a conservação ambiental. Belém, IMAZON.

Arima E., Veríssimo A., 2002. Brazil em ação: ameaças e oportunidades econômicas na fronteira amazônica, Belém, IMAZON.

Arnauld de Sartre, Xavier; Taravella, Romain. 2009, « National sovereignty vs. sustainable development. Lessons from the narrative on the internationalisation of the Brazilian Amazon », Political geography, 26 (7), p. 406-415.

Arnauld de Sartre, Xavier; Berdoulay, Vincent. 2011, Des politiques territoriales durables? Leçons d'Amazonie. Paris, Quae.

Bailey I., Maresh S., 2009. Scales and networks of neoliberal climate governance: the regulatory and territorial logics of European Union emissions trading. Transactions of the Institute of British Geographers, 35, 445-461.

Barth, F., 1969. Introduction. In Barth, F., (Ed.), Ethnic groups and boundaries : the social organization of culture difference. George Allen/Unwin. Bergen/Oslo/London, pp.9-38.

Becker, B. K., 2004. Amazônia. Geopolítica na virada do III milênio. Rio de Janeiro: Garamond.

Becker, H.O., 1998. Tricks of the Trade: How to Think about Your Research While You're Doing It. The University of Chicago Press ; Chicago.

Boltanski, L., Thévenot, L., 1991. De la justification. Les économies de la grandeur. Gallimard, Paris.

Bourdieu, P., 1994. Raisons pratiques. Sur la théorie de l'action. Seuil, Paris.

Brandon, K., Redford, K.H., Sanderson, S.E. (eds), 1998. Parks in peril: people, politics and protected areas. Island Press, Washington D.C.

Brannstrom, C., 2001. Producing possession: labour, law and land on a Brazilian agricultural frontier, 1920-1945. Political Geography 20, 859-883.

Brasil, 2005. Plano Agrícola e Pecuário 2004/2005. Minitério da Agricultura, Pecuária e Abastecimento, Brasil.

Brésil, 2006. Discours de politique étrangère du président Lula (Paris - Sorbonne 13 juillet 2005). In Monclaire, S., Deluchet, J. F. (eds), Gouverner l'intégration : les politiques nationale et internationale du Brésil de Lula. Editions Pepper, Paris.

Browder, J.O., 1992. The limits of extractivism. BioScience 42, 174-182.

Brown, J.C., Purcell, M., 2005. There's nothing inherent about scale: political ecology, the local trap and the politics of development in the Brazilian Amazon. Geoforum 36, 607-624.

Bulkeley H., 2005. Reconfiguring environmental governance: Towards a politics of scales and networks. Political Geography, 24 (8), 875-902.

Campos, M.T., Nepstad, D.C., 2006. Smallholders, the Amazon's new conservationists. Conservation Biology 5 (20), 1553-1556. 
Castellanet, C., Jordan, C. F., 2002. Participatory Action-Research in Natural Resource Management. A critique of the Method based on Five Years' Experience in the Transamazônica Region of Brazil. Taylor and Francis, New York.

Castro, E., Monteiro, R., Castro, C.P., 2002. Atores e relações sociais em "novas fronteiras" do desmatamento na Amazônia (São Félix do Xingu, Novo Progresso, Castelo dos Sonhos). Banco Mundial, Belém.

Cattaneo, A., 2005. Inter-regional innovation in Brazilian agriculture and deforestation in the Amazon: income and environment in the balance. Environment and Development Economics 10, 485511.

Cirne Lima, L. F., 2005. L'EMBRAPA : 30 ans de recherche agronomique. Ingénieurs de la Vie 2005 : $472-473$

Costa, F. A., 1998. Ciência, tecnologia e sociedade na Amazônia. Questões para o desenvolvimento sustentável. Cejup, Belém.

Delaney D., Leitner H., 1997. The political construction of scale. Political Geography, 16 (2), 93-97.

Estado do Pará, 2004. Proposta para discussão do Macro Zoneamento Ecológico Econômico do Estado do Pará. Governo do Pará, Belém.

Esterci, N., 1996. Imobilização por dívida e formas de dominação no Brasil de hoje. Lusotopie 1996, 123-137.

Fearnside P.M., 2001. Land-Tenure Issues as Factors in Environmental Destruction in Brazilian Amazonia: The Case of Southern Pará. World Development, 29 (8), 1361-1372.

Fernandes, M., 1999. Donos de terras. Trajetoria da União Democratica Ruralista - UDR. UFPA/NAEA, Belém.

Geffray, C., 1995. Chroniques de la servitude en Amazonie brésilienne. Essai sur l'exploitation paternaliste. Karthala, Paris.

GEOMA, 2005. Dinamica territorial da frente de ocupação de São Félix do Xingu-Iriri. Sumário executivo da Missão de Campo na região de São Félix do Xingu/Iriri, 13 a 18 de outubro de 2004. MCT. MPEG-INPE-INPA-UFPa-EMBRAPA, Brasìlia.

Hecht S., Cockburn A., 1990. The fate of the forest. Developers, destroyers and defenders of the Amazon, Harper Collins Publishers, New York, 355 p.

Hecht, S.B., 1993. Logics of livestock and deforestation : the case of Amazonia. In Downing, T.E., Hecht, S.B., Pearson, H.A., Downing, C.G. (eds), Development or Destruction : The Conversion of Tropical Forests to Pasture in Latin America, Westview Press, Boulder, pp. 7-25.

IBGE, 2006. Produção animal no $2^{\circ}$ Trimestre de 2006. IBGE, Brasília.

Kaimowitz, D., Mertens, B., Wunder, S., Pacheco, P., 2004. Hamburger Connection Fuels Amazon Destruction: Cattle ranching and deforestation in Brazil's Amazon. Center for International Forestry Research (CIFOR), Bogor.

Kaimowitz, D., Angelsen, A., 1999. Will livestock intensification help save latin america's tropical forests ?. Tropical Agronomy Center for Research and Higher Education. Turrialba.

Karkkainen B.C., 2004. Post-sovereign environmental governance. Global environmental politics, 4 (1), 72-96.

Lafaye, C., Thévenot, L., 1993. Une justification écologique ? Conflits dans l'aménagement de la nature. Revue Française de Sociologie 34, 495-524.

La Rouche, L., 2001. Máfia verde: o ambientalismo a seviço do governo mundial. Executive Intelligence Review, Rio de Janeiro. 
Laurance W., Cochrane M., Gergen S., Fearnside P., Delamìnica P., Barber C., d'Angelo S., Fernandes T., 2001. The future of the Brasilian Amazon. Science, 291 (5503), 438-444.

Léna P., 1999. La forêt amazonienne: un enjeu politique et social contemporain. Autrepart (9), 97-120.

Little, P. E., 2001. Amazonia: territorial struggles on perennial frontiers. The John Hopkins University Press, Baltimore.

Lyotard, J.-F., 1979. La Condition postmoderne: rapport sur le savoir. Éditions de Minuit, Paris.

McCarthy J., 2005. Scale, Sovereignty and strategy in environmental governance. Antipode, 37, 731753.

Manson S.M., 2008. Does scale exist? An epistemological scale continuum for complex humanenvironment systems. Geoforum, 39 (2), 776-788.

Mermet, L., 1992. Stratégies pour la gestion de l'environnement. La nature comme jeu de société ?. L'Harmattan, Paris.

Mermet, L., Billé, R., Leroy, M., Narcy, J. B., Poux, X., 2005. L'analyse stratégique de la gestion environnementale : un cadre théorique pour penser l'efficacité en matière d'environnement. Natures, Sciences, Sociétés 13, 127-137.

Ministério do Meio Ambiente - MMA, 2001. Avaliação e identificação de ações prioritarias para a conservação, utilização sustentável e repartição dos beneficios da biodiversidade na Amazônia brasileira. MMA, Brasília.

Mol, A.P.J., 2000. The environmental movement in an era of ecological modernisation. Geoforum 31 (1), 45-56.

Myers, N., 1981. The Hamburger Connection: How Central America's Forests Became North America's Hamburgers. Ambio 10: 3-8.

Neumann R.P., 2004. Nature-State territory: toward a critical theorization of conservation enclosures. In: Liberation ecologies: environment, development and social movement (Peet R., Watts M. eds.), Routledge, London, pp. 195-217.

Neumann R.P., 2009. Political ecology: theorizing scale. Progress in Human Geography, 33 (3), 398406.

Nunes, W. S., 1998. Conversando com o Xingu. Belém : Unigraf.

Peixoto, R., 1996. A cultura politica na fronteira do Sul do Pará. In: L'oppression paternaliste au Brésil (Léna, P., Geffray, C., Araujo, R. eds.), Lusotopie. Karthala, Paris, pp. 253-269.

Peres, C.A., Terborgh, J.W., 1995. Amazonian nature reserves: an analysis of the defensibility status of existing conservation units and design criteria for the future. Conservation Biology 9, 34-46.

Piancastelli, M., Perobelli, F. 1996. ICMS: Evolução Recente e Guerra Fiscal. Texto para Discussão n402. IPEA, Brasília.

Redford, K.H., 1992. The empty forest. Bioscience 42, 412-422.

Rossi, G., 2001. L'ingérence écologique. Environnement et développement rural du Nord au Sud. CNRS Editions, Paris.

Santiago, A.A., 1972. O Zebu na India, no Brasil e no mundo. Instituto Camponese de Ensino Agricola, Campinas.

Sayre N., 1999. The cattle boom in southern Arizona: Towards a critical political ecology. Journal of the Southwest, 41 (2), 239-271.

Schmink, M., Wood, C. H., 1992. Contested frontiers in Amazonia, Columbia University Press, New York. 
Schneider, R., Arima, E., Veríssimo, A., Barreto, P., Souza Jr., C., 2000. Amazônia Sustentavél: limitante e oportunidades para o desenvolvimento rural. IMAZON/Banco Mundial, Belém/Brasília.

Simmons, C.S., Walker, R.T., Arima, E.Y., Aldrich, S.P., Caldas, M.M., 2007. The Amazon Land War in the South of Pará. Annals of the Association of American Geographers 97(3): 567 - 592.

Smith, N., 1993. Homeless/global: scaling places. In: Bird, J. (ed.), Mapping the Futures: Local Cultures Global Change. Routledge, New York, pp. 87-119.

Souza, A. P. S., 2006. O desenvolvimento socioambiental na Transamazônica: a trajetoria de um discurso de muitas vozes. Mestrado do Nucleo de Estudos Integrados de Agricultura Familiar. Universidade Federal do Pará, Belém.

Taravella, R., 2008. La frontière pionnière amazonienne aujourd'hui : projet socio-environnemental de conservation forestière contre dynamique pastorale de déforestation. Une analyse stratégique 2000-2006 de l'action collective en «Terra do Meio » (Pará, Brésil). Thèse de doctorat en Sciences de l'Environnement d'AgroParisTech-Engref.

Théry, H., Mello, N.A., 2005. Atlas do Brasil, Disparidades e dinâmicas do território. EDUSP, São Paulo.

Veiga, J. B., Tourrand, J.-F., Piketty, M. G., Poccard-Chapuis, R., Alves, A. M. et Thales, M. C., 2004. Expansão e trajetórias da pecuária na Amazônia. Pará, Brasil. Editora UnB, Brasília.

Veiga, J.B., Poccard-Chapuis, R., Tourrand, J.-F., 2003. Caracterização e viabilidade agropecuária na agricultura familial da Amazônia Oriental brasileira. In Tourrand, J.-F., Veiga, J. B. (Eds), Viabilidade de sistemas agropecuarios na agricultura familiar da Amazônia. FUNTEC, Belém, pp. 17-63.

Velasquez, C. Villas Boas, A. Schwartzman, S., 2006. Desafio para a gestão ambiental integrada em território de fronteira agrícola no oeste do Pará. Revista de Admnistração Pública 40(6), 10611075 .

XINGURI, 2003. Ata de criação da Associação dos produtores rurais das terras do meio.

XINGURI, 2005a. Carta ao governador do Estado do Pará. Tucumã.

XINGURI, 2005b. Manifesto. Tucumã.

Walker R., Moran E., 2000. Deforestation and Cattle Ranching in the Brazilian Amazon: External Capital and Household Processes. World Development, 28 (4), 683-699.

Walker, R., Browder, J., Arima, E., Simmons, C., Pereira, R., Caldas, M., Shirota, R., Zen, S.d., 2009. Ranching and the new global range: Amazônia in the 21st century. Geoforum 40 (5), 732-745.

Zimmerer, K.S., 2006. Geographical perspectives on globalization and environmental issues: the interconnections of conservation, agriculture and livelihoods, in: Zimmerer, K.S. (Ed.), Globalization \& new geographies of conservation. University of Chicago Press, Chicago, pp. 143. 